DOI: $10.21802 / \operatorname{artm} .2021 .1 .17 .38$.

UDC 615.127-005.8-06-004-037-08:614.212

\title{
ASSESSMENT OF RE-HOSPITALIZATION PROBABILITY IN PATIENTS WITH POST-INFARCTION CARDIOSCLEROSIS AND COMORBID PATHOLOGY
}

\author{
M.Yu. Koteliukh
}

\author{
Kharkiv National Medical University, Department of Internal Medicine No.2 and Clinical Immunology and \\ Allergology named after academician L.T. Malaya, Kharkiv, Ukraine, \\ ORCID ID: 0000-0001-6090-4835, e-mail: koteliukh@gmail.com
}

\begin{abstract}
The aim of our research was to examine the risk factors for re-hospitalization in patients with acute myocardial infarction with concomitant diabetes mellitus (DM) 2 type or obesity.

Materials and methods. The research involved examination of 262 patients with post-infarction cardiosclerosis in combination with type $2 \mathrm{DM}$ or obesity. They were divided into groups: Group 1 included 96 patients who were not hospitalized for 12 months; comparison group 2 consisted of 166 patients who were hospitalized to an in-patient department. The average age of the first group was $65.13 \pm 1.43$ years, the comparison group $-63.47 \pm 1.28$ years. Patients were divided into 3 groups to assess the value of CTRP 3 in chronic heart failure (CHF): Group 1 included 80 patients with post-infarction cardiosclerosis without type $2 \mathrm{DM}$ or obesity, Group 2 consisted of 74 patients with post-infarction cardiosclerosis with type $2 \mathrm{DM}$, Group 3 comprised 60 patients with post-infarction cardiosclerosis and obesity. The research included patients who were treated at the State Institution "L.T. Malaya National Institute of Therapy of the National Academy of Medical Sciences of Ukraine" and in the first cardiology department of Kharkiv Clinical Hospital or Rail Transport No.1 of the "Healthcare Center" branch of the Joint Stock Company "Ukrainian Railways". Determination of cartonectin and adropin levels was performed by enzyme-linked immunosorbent assays using the commercial test system Human CTRP 3 (Aviscera Bioscience Inc, Santa Clara, USA) and Human Adropin (Elabscience Biotechnology, USA). Statistical processing of the obtained data was performed using the statistical software package "IBM SPPS Statistics 27.0" and "GraphPad Prism software version 9.0.2". For all types of analysis, the differences were considered statistically significant at $\mathrm{p}<0.05$. One-factor analysis of variance was used to characterize the influence of factors on the indicators. The method of discriminant analysis was used to assess the occurrence of re-hospitalization.

Results. The research revealed a decrease in CTRP 3 in the progression of CHF in patients with post-infarction cardiosclerosis in the presence and absence of concomitant type $2 \mathrm{DM}$ or obesity. The effect of diastolic blood pressure, CHF, glucose, the presence of type 2 DM and obesity on the content of CTRP 3 and adropin was determined. Cartonectin has been shown to be a risk factor for re-hospitalization. An assessment scale for the likelihood of re-hospitalization in patients with post-infarction cardiosclerosis and concomitant type $2 \mathrm{DM}$ or obesity has been developed. We analyzed clinical cases of re-hospitalization among patients with post-infarction cardiosclerosis in the presence of concomitant pathology.

Conclusions: CTRP 3 has been shown to be associated with the progression of CHF in patients with post-infarction cardiosclerosis and comorbid pathology. The results indicate the effect of hypertension, CHF, type 2 DM and obesity on the content of cartonectin and adropin. As a result, it has been shown that cartonectin is a factor influencing the occurrence of re-hospitalization in patients with post-infarction cardiosclerosis in the presence of syntropic pathology. The proposed method allows to assess the likelihood of re-hospitalization in patients with post-infarction cardiosclerosis with comorbid pathology.
\end{abstract}

Keywords: cartonectin, diabetes, factor, hospitalization, obesity.

Introduction. Coronary heart disease (CHD) is an important problem in practical medicine, as it requires special measures to prevent such a disease with combined syntropic pathology [11]. At the same time, the primary measure is the statistical determination of cases of re-hospitalization of patients to the hospital due to the available risk factors under conditions of polymorbidity. Recently, an important step in solving this problem has been the search for a set of risk factors that can statistically determine the number of re-hospitalizations among patients who have suffered an acute myocardial infarction (AMI) under conditions of polymorbidity. For example, it has been established that such indicators are factors that characterize the occurrence of AMI and have a significant impact on the development of late complications after myocardial infarction in the presence of diabetes mellitus (DM) 2 type and obesity [4].

Despite significant advances in modern medicine, CHD remains the most pressing medical and social problem, affecting all leading medical and demographic indicators (morbidity, mortality, disability, life expectancy, hospitalization). One of the reasons for the high rates of rehospitalization is the presence of recurrent myocardial infarction and progression of heart failure in patients with myocardial infarction, indicating a lack of preventive activity among patients and physicians, which should be aimed at preventing the development and progression of the disease, risk factors and daily medication. Refusal to take drugs in patients with post-infarction cardiosclerosis causes complications of this disease. Poor compliance with 
drug therapy and insufficient correction of CHD risk factors after myocardial infarction have been shown to result in repeated hospitalizations for decompensation of chronic heart failure $(\mathrm{CHF})$, recurrent myocardial infarction and fatalities. In AMI, the timing of medical care is known to play a crucial role. Unfortunately, most patients arrive at the hospital with a significant delay [5].

Adipokines and energy homeostasis are known to affect the course of AMI in concomitant pathology. $\mathrm{C} 1 \mathrm{q} / \mathrm{TNF}-$ related protein 3 (CTRP 3 or cartonectin) is an adipokine which is involved in the regulation of carbohydrate and lipid metabolism in patients with cardiovascular disease. It has cardioprotective properties and affects cardiac function in patients with acute myocardial infarction and heart failure. The role of cartonectin in lipid metabolism and inhibition of inflammation makes this molecule an important indicator as a risk factor for the occurrence and progression of CHD with concomitant type $2 \mathrm{DM}$ or obesity. The results of further researches necessary to clarify the interaction of cartonectin with other cellular and humoral factors of the inflammatory process may allow in practice to use cartonectin as a risk factor to determine rehospitalization in patients with post-infarction cardiosclerosis and syntropic pathology $[3 ; 6]$.

Rationale for the research. The main problem today is that there are no data on the assessment of the occurrence of re-hospitalization in the presence of risk factors in patients with a combined course of post-infarction cardiosclerosis, type $2 \mathrm{DM}$ and obesity.

The purpose of the research: to identify risk factors that affect the risk of re-hospitalization in patients with post-infarction cardiosclerosis and comorbid pathology.

Materials and methods. The research involved examination of 262 patients, including 54 women (20.6\%) and 208 men (79.4\%), who were hospitalized to the intensive care unit of the State Institution "L.T. Malaya National Institute of Therapy of the National Academy of Medical Sciences of Ukraine" and in the first cardiology department of Kharkiv Clinical Hospital or Rail Transport No.1 of the "Healthcare Center" branch of the Joint Stock Company "Ukrainian Railways". Patients were divided into 3 groups to assess the value of CTRP 3 in CHF: Group 1 included 80 patients with post-infarction cardiosclerosis without type 2 DM or obesity, Group 2 comprised 74 patients with post-infarction cardiosclerosis with type $2 \mathrm{DM}$, Group 3 consisted of 60 patients with post-infarction cardiosclerosis and obesity. According to the research design, patients who participated in the assessment of cases of rehospitalization were divided into the following groups: Group 1 involved 96 patients who were not hospitalized for 12 months, the comparison group (Group 2) included 166 patients who were hospitalized to the in-patient department. The average age of Group 1 patients was $65.13 \pm 1.43$ years, the comparison group $-63.47 \pm 1.28$ years.

The diagnosis of myocardial infarction was determined according to the ESC / ACCF / AHA 30 / WHF criteria (2012) [5]. The diagnosis of CHF was determined according to the recommendations of the ESC (2016) [9].
Diagnosis of diabetes was made according to the criteria of the International Diabetes Federation (IDF) (2019) [8]. Diagnosis of type 2 diabetes was established in accordance with the recommendations of the American Diabetes Association (ADA) and the European Association for the Study of Diabetes (EASD) according to the criteria for diagnosing diabetes $[1 ; 13]$. The body mass index (Kettle's index) was determined to characterize obesity, which was calculated by the following formula: weight $(\mathrm{kg}) /$ height $\left(\mathrm{m}^{2}\right)$. The European recommendations of 2018 were used to determine the diagnosis. [12].

The design of the research was approved by the Ethics Commission of Kharkiv National Medical University (Minutes No.2 of 2 April 2018). All patients who participated in the research signed a voluntary informed consent to participate.

Inclusion criteria were post-infarction cardiosclerosis, hypertension, $\mathrm{CHF}$, type $2 \mathrm{DM}$, obesity.

Exclusion criteria were type $1 \mathrm{DM}$, autoimmune diseases, diffuse connective tissue diseases, pituitary and hypothalamic diseases, thyroid disease, the presence of symptomatic hypertension, valvular heart disease, CHF IV FC to myocardial infarction, the presence of chronic obstructive pulmonary disease, apparent diseases of kidneys and liver, severe anemia, cancer.

Determination of cartonectin and adropin levels was performed by enzyme-linked immunosorbent assays using the commercial test system Human CTRP 3 (Aviscera Bioscience Inc, Santa Clara, USA) and Human Adropin (Elabscience Biotechnology, USA).

Statistical processing of the obtained data was performed using the statistical software package "IBM SPPS Statistics 27.0" (IBM Inc., USA, license No. LCZAA-BKKMKE) and "Prism version 9.0.2" (GraphPad software, USA, Serial No. GPS-2050439-TCSZ-2EDFF). For all types of assessment, the differences were considered statistically significant at $p<0.05$. One-way assessment of variance was used to characterize the influence of factors on the indicators. The method of discriminant analysis was used to assess the occurrence of re-hospitalization.

Results. We compared CTRP3 level and chronic heart failure according to the NYHA classification between classes II and III in patients with post-infarction cardiosclerosis in the presence and absence of type $2 \mathrm{DM}$ or obesity. $38.75 \%$ (31) of patients with post-infarction cardiosclerosis without type $2 \mathrm{DM}$ and obesity had functional class NYHA II, $61.25 \%$ (49) - NYHA III. 33.8\% (25) of patients with post-infarction cardiosclerosis and type 2 DM had functional class NYHA II, 66.2\% (49) - NYHA III. $43.3 \%$ (26) of patients with post-infarction cardiosclerosis and obesity had functional class NYHA II, 56.7\% (34) - NYHA III. The research showed that the more progressive the NYHA class of symptoms, the lower the CTRP3 concentrations (Figs. 1a and b) in patients with post-infarction cardiosclerosis and type $2 \mathrm{DM}$. This tendency to decrease CTRP3 (Fig. 1c) was observed in patients with post-infarction cardiosclerosis and obesity, but was not statistically significant when comparing groups $(\mathrm{p}>0.05)$. 
A

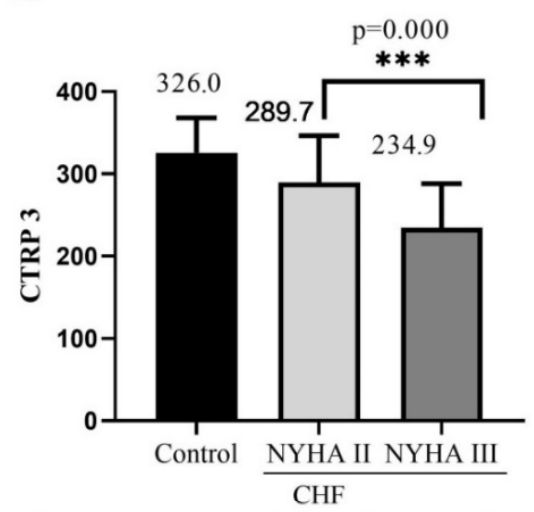

Patients with post-infarction cardiosclerosis C

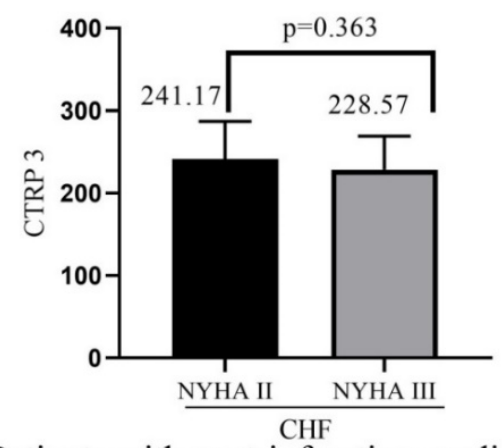

B

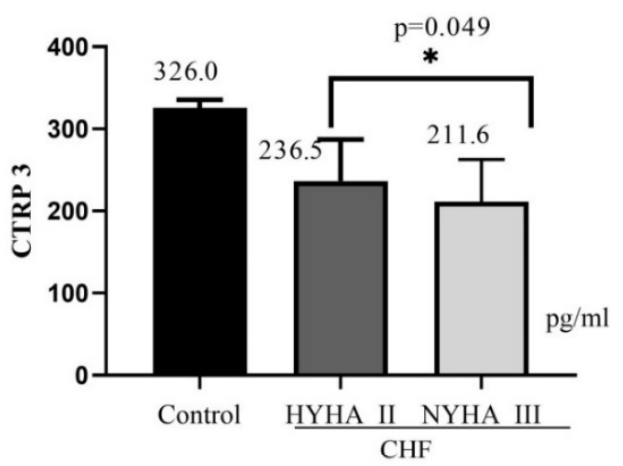

Patients with post-infarction cardiosclerosis and 2 type DM

Note: $* \mathrm{p}<0.05, * * * \mathrm{p}<0.001$

Patients with post-infarction cardiosclerosis and obesity

Fig. 1. Determination of cartonectin content in patients with post-infarction cardiosclerosis depending on the presence of type 2 diabetes or obesity

The research implied evaluation of the factors influencing the increase in the probability of re-hospitalization in patients with combined post-infarction cardiosclerosis, type $2 \mathrm{DM}$ or obesity.

The method of discriminant analysis revealed that statistically significant $(p<0.001)$ and the most important were the following objective indicators: the level of cartonectin, age, hypertension, effective therapy, CHF (Table $1)$.

Table 1

\begin{tabular}{|c|c|}
\multicolumn{2}{|c|}{ Structural matrix } \\
\hline Risk factors & Function \\
\hline Age, years & 0.619 \\
\hline Hypertensive disease & 0.450 \\
\hline Effective therapy & 0.168 \\
\hline Cartonectin level & 0.075 \\
\hline Chronic heart failure & 0.732 \\
\hline
\end{tabular}

Standardized coefficients of canonical discriminant function determine the 3 main negative risk factors that affect the likelihood of re-hospitalization of patients within 12 months after myocardial infarction and determine their relative importance: hypertension, age, $\mathrm{CHF}$ (Table 2).
Table 2

Standardized coefficients of the canonical discriminant function

\begin{tabular}{|c|c|}
\hline Risk factors & Function \\
\hline Hypertensive disease & 0.208 \\
\hline Chronic heart failure & 0.715 \\
\hline Age, years & 0.584 \\
\hline
\end{tabular}

The main concomitant risk factors can be identified on the basis of factor analysis by determining the main components that are most important in the group of hospitalized patients within 12 months after myocardial infarction with comorbid pathology (Table 3 ).

Table 3

Indicators are not included in the formula

\begin{tabular}{|l|c|}
\hline \multicolumn{1}{|c|}{ Risk factor } & $\begin{array}{c}\text { The value at which the } \\
\text { factor is removed }\end{array}$ \\
\hline Hypodynamia & 0.917 \\
\hline Obesity cholesterol level & 0.858 \\
\hline $\begin{array}{l}\text { Total } \\
\text { (mmol/l) }\end{array}$ & 0.857 \\
\hline The level of adropin $\mathrm{pg} / \mathrm{ml}$ & 0.903 \\
\hline
\end{tabular}

The best favorable concomitant factor that reduces the risk of hospitalization within 12 months after myocardial infarction, identified on the basis of factor analysis using the method of the main components is adropin (Table 3). However, this indicator was not 
included in the formula and was not further considered as a significant factor.

The formula for calculating the number of points that determine the occurrence of re-hospitalization within 12 months after myocardial infarction in patients with concomitant DM or obesity is as follows:

Points (probability of re-hospitalization) = $0.106 *$ Age $+0.636 *$ Hypertension $+0.197 *$ Effective therapy $+0.002 *$ CTRP3 $+2.27 *$ Chronic heart failure 11.727, where: Age in years, Hypertension: 1 - absent; 2 present, Effective therapy: 1 - absent; 2 - present, CTRP3
- cartonectin value, Chronic heart failure: 1 - absent; 2 present.

Then, after receiving the result according to the formula, it is necessary to determine the probability of rehospitalization within 12 months after myocardial infarction with syntropic pathology (Table 4).

The proposed method allows to determine the probability of re-hospitalization with an accuracy of $92 \%$ and has an overall sensitivity of $92.2 \%$ and a specificity of $91.7 \%$ (Table 5).

Evaluation scale for re-hospitalization within 12 months afte

Evaluation scale for re-hospitalization within 12 months after myocardial infarction with syntropic pathology
\begin{tabular}{|c|c|c|}
\hline Number of points & Probability of re-hospitalization & Probability of no re-hospitalization \\
\hline More than 1 & $100 \%$ & $0 \%$ \\
\hline From 0 to 1 & $80 \%$ & $20 \%$ \\
\hline From 0 to -1 & $74 \%$ & $26 \%$ \\
\hline Less than -1 & $7 \%$ & $93 \%$ \\
\hline
\end{tabular}

Table 4

Table 5

\begin{tabular}{|c|c|c|c|c|}
\hline \multicolumn{5}{|c|}{ Classification of results } \\
\cline { 3 - 5 } \multicolumn{2}{|c|}{ Re-hospitalization within 12 months } & Expected group membership & \multirow{2}{*}{ Total } \\
\hline \multirow{2}{*}{ Number } & No & 88 & Yes & 96 \\
\cline { 2 - 5 } & Yes & 13 & 153 & 166 \\
\hline \multirow{2}{*}{$\%$} & No & 91.7 & 8.3 & 100.0 \\
\cline { 2 - 5 } & Yes & 7.8 & 92.2 & 100.0 \\
\hline
\end{tabular}

Note: $92.0 \%$ of initially grouped cases are correctly classified.

One-factor analysis of variance revealed the effect of diastolic blood pressure $(\mathrm{F}=1.77 ; \mathrm{p}=0.03)$, the presence of CHF $(\mathrm{F}=5.93 ; \mathrm{p}=0.02)$ on the content of CTRP 3 and the level of adropin $(F=4.33 ; p=0.04)$, glucose content at the level of CTRP $3(\mathrm{~F}=1.44 ; \mathrm{p}=0.04)$ and on the content of adropin $(F=1.39 ; \mathrm{p}=0.05)$, type 2 diabetes at the content of CTRP $3(\mathrm{~F}=7.81 ; \mathrm{p}=0.006)$ and on the level of adropin $(F=12.094 \mathrm{p}=0.001)$, obesity on the concentration of CTRP $3(\mathrm{~F}=12.7 ; \mathrm{p}=0.000)$ and on the content of adropin $(\mathrm{F}=3.99 ; \mathrm{p}=0.047)$.

Clinical case 1. A 65-year-old patient $\mathrm{K}$. is diagnosed with CHD, post-infarction cardiosclerosis. According to the patient, he suffers from type $2 \mathrm{DM}$. He regularly takes medication. He has suffered from hypertension for 8 years with maximum figures up to $200 / 100 \mathrm{mmHg}$. Last year, the patient had an AMI, was discharged with an improvement in clinical condition and subsequently underwent follow-up examination as an outpatient by a family doctor. He went to the family doctor for medical help due to the deterioration of his general condition. Examination revealed the presence of obesity. Blood pressure was $150 / 90 \mathrm{mmHg}$. Heart rate -82 beats per minute, pulse 82 beats per minute, respiratory rate -20 breaths per minute. The family doctor determined that the patient had CHF. The level of cartonectin was $195.56 \mathrm{pg} / \mathrm{ml}$ (norm in the range from 274.59 to $399.96 \mathrm{pg} / \mathrm{ml}$ ). Using the formula, we obtained: Points (risk) $=0.106 * 65+0.636 * 2+$ $0.197 * 1+0.002 * 195.56+2.27 * 2-11.727=6.89+1.272$ $+0.197+0.39112+4.54-11.727=1.56$. According to the scale developed by us, if the number of points is more than 1 , the probability of hospitalization is $100 \%$. Therefore, the patient should be hospitalized immediately to prevent adverse complications of post-infarction cardiosclerosis with concomitant pathology.

Clinical case 2. A 55-year-old patient $\mathrm{S}$. is diagnosed with CHD, post-infarction cardiosclerosis. According to the patient, he suffers from type $2 \mathrm{DM}$. He regularly takes medication. He has suffered from hypertension for 5 years with maximum figures up to $160 / 90 \mathrm{mmHg}$. The patient had an AMI last year, underwent a course of rehabilitation. He went to the family doctor for a routine checkup. On examination: the patient is of a sufficient physique, without signs of excess body weight. Blood pressure was 130/80 mmHg. Heart rate -76 beats per minute, pulse 76 beats per minute, respiratory rate -17 breaths per minute. The patient showed no signs of CHF. The level of cartonectin was $282.4 \mathrm{pg} / \mathrm{ml}$ (norm in the range from 274.59 to $399.96 \mathrm{pg} / \mathrm{ml}$ ). Using the formula, we obtained: Points (risk) $=0.106 * 55+0.636 * 2+0.197 * 1+$ $0.002 * 282.4+2.27 * 1-11.727=5.83+1.272+0.197+$ $0.5648+2.27-11.727=-1.59$. According to the rating scale, if the number of points is less than -1 , the probability of no hospitalization is $93 \%$, and the possibility of hospitalization is only $7 \%$. Therefore, the patient should undergo outpatient screening of the general condition and in consultation with the patient to conduct outpatient treatment. In this case, hospitalization of the patient to the hospital is not required.

Discussion. According to a research, CTRP 3 is a new adipokine that affects the metabolism, inflammation and development of CHD. The experimental model showed a significant decrease in CTRP 3 after myocardial infarction, which does not contradict our results [14]. One of the late complications of AMI is the development of 
CHF. Obesity is known to be a global problem and increases the risk of type $2 \mathrm{DM}$ and CHD. Adipose tissue produces many pro-inflammatory and anti-inflammatory adipokines. Adipokin CTRP 3 has anti-inflammatory and cardioprotective properties [6]. Obesity and type 2 diabetes are associated with an increased risk of CHF and in the future is one of the causes of death $[2 ; 10]$. In our research, we found a low level of CTRP 3 in the presence of CHF according to the NYHA classification in patients with AMI with and without type $2 \mathrm{DM}$ or obesity. According to the results of the research, the content of CTRP 3 was associated with the occurrence of systolic dysfunction. In patients with systolic dysfunction, the level of CTRP 3 is significantly lower compared to preserved systolic function [3]. We determined a significant effect of diastolic blood pressure, CHF, glucose, the presence of type $2 \mathrm{DM}$ and obesity on the content of CTRP 3 . The results do not contradict the literature, according to which it was determined that there is a negative relationship between CTRP3 concentration and the presence of type $2 \mathrm{DM}, \mathrm{BMI}$ and article [7].

According to scientific search, we have identified significant factors that lead to re-hospitalization in patients with myocardial infarction with comorbidities. Such factors include the presence of hypertension, chronic heart failure, age, cartonectin content and the effectiveness of drug therapy. Based on the results of calculating the points according to the formula, we have developed a scale for assessing the occurrence of re-hospitalization. We determined that cartonectin is not only an indicator of the development of chronic heart failure, but also acts as a risk factor for re-hospitalization.

The proposed method allows to determine with a high degree of accuracy re-hospitalization in patients with post-infarction cardiosclerosis and comorbid pathology, which, in turn, reduces the economic cost of emergency care and increases hospital funding to provide quality medical services to patients.

\section{Conclusions:}

1. Low CTRP 3 has been found to be associated with the progression of $\mathrm{CHF}$ in patients with post-infarction cardiosclerosis and concomitant type 2 DM or obesity.

2. Cartonectin and adropine levels have been shown to be associated with risk factors such as hypertension, $\mathrm{CHF}$, obesity and type $2 \mathrm{DM}$ in patients with post-infarction cardiosclerosis in the presence of syntropic pathology.

3. The proposed method allows to assess the risk of rehospitalization in patients with post-infarction cardiosclerosis with comorbid pathology.

\section{References:}

1. Cosentino F, Grant PJ, Aboyans V, Bailey CJ, Ceriello A, Delgado V, et al. 2019 ESC Guidelines on diabetes, pre-diabetes, and cardiovascular diseases developed in collaboration with the EASD: The task force for diabetes, pre-diabetes, and cardiovascular diseases of the European society of cardiology and the European association for the study of diabetes (EASD). Eur Heart J [Internet]. 2020; Jan, 7 [cited 2021 Mar 07]; 41(2):255323. Available from: https://academic.oup.com/ eurheartj/article/41/2/ 255/ 5556890? login=true DOI:10.1093/eurheartj/ehz486
2. Csige I, Ujvarosy D, Szabo Z, Lorincz I, Paragh G, Harangi $\mathrm{M}$, et al. The impact of obesity on the cardiovascular system. J Diabetes Res. 2018; Nov, 04 [cited 2021 Mar 08]; 2018. Available from: https://www.hindawi.com/journals/jdr/ 2018/ 34073 06/ DOI: 10.1155/2018/3407306

3. Gao C, Zhao S, Lian K, Mi B, Si R, Tan Z, et al. C1q/TNF-related protein 3 (CTRP3) and 9 (CTRP9) concentrations are decreased in patients with heart failure and are associated with increased morbidity and mortality. BMC Cardiovasc Disord. 2019; Jun, 10 [cited 2021 Mar 05]; 19(139). Available from: https://bmccardiovascdisord.biomedcentral.com/articles/10.1186/s12872-019-1117-0 DOI: $10.1186 / \mathrm{s} 1$ 2872-019-1117-0

4. Kiani F, Hesabi N, Arbabisarjou A. Assessment of risk factors in patients with myocardial infarction. Glob J Health Sci. 2016; May, 28 [cited 2021 Mar 05]; 8(1):255-62. Available from: http://dx.doi.org/10.5539/gjhs.v8n1p255

5. Kristian Thygesen, Joseph S. Alpert, Allan S. Jaffe, Maarten L. Simoons, Bernard R. Chaitman, Harvey D. White, et al. Third universal definition of myocardial infarction. Circulation [Internet]. 2012; Oct, 16 [cited 2021 Mar 05]; 126:2020-35. Available from: https://www.ahajournals.org/doi/full/10.1161/ CIR.0b013e31826 e1058 DOI:10.1161/ CIR.0b013e31826e1058

6. Lau WB, Ohashi K, Wang Y, Ogawa H, Murohara T, Ma Xin-Liang, et al. Role of adipokines in cardiovascular disease. Circulation [Internet]. 2017; Jun, 10 [cited 2021 Mar 08]; 81(7):920-8. Available from: https://www.jstage.jst.go.jp/ article/circj/81/7/81_CJ17-0458/_article DOI:10.1253/circj.CJ-17-0458

7. Moradi N, Najafi M, Sharma T, Fallah S, Koushki M, Peterson JM, et al. Circulating levels of CTRP3 in patients with type 2 diabetes mellitus compared to controls: A systematic review and meta-analysis. Diabetes Res and Clin Pract. 2020; Nov, [cited 2021 Mar 08]; P.169. Available from: https://www.sciencedirect.com/ science/article/abs/pii/S0168822720307063 DOI: $10.1016 /$ j.diabres.2020.108453

8. Online version of IDF Diabetes Atlas: Nineth edition; 2019; [cited 2021 Mar 05]. Available from: https://www.diabetesatlas.org/en/

9. Ponikowski P, Voors AA, Anker SD, Bueno H, Cleland JGF, Coats AJS, et al. 2016 ESC Guidelines for the diagnosis and treatment of acute and chronic heart failure The Task Force for the diagnosis and treatment of acute and chronic heart failure of the European Society of Cardiology. Eur Heart J. [Internet]. 2016; May, 20 [cited 2021 Mar 08]; 37:2129-200. Available from: https:// academic. oup.com/eurheartj/article/37/27/2129/1748921 DOI:10.1093/ eurheartj / ehw128

10. Rosano Giuseppe MC, Vitale C, Seferovic P. Heart failure in patients with diabetes mellitus. Card Fail. Rev. 2017; [cited 2021 Mar 08]; 3(1):52-5. Available from: https://www.radcliffecardiology.com/articles/heart-failure-patients-diabetes-mellitus DOI: 10 . 15420/cfr.2016:20:2

11. Ryndina NG, Kravchun PG, Yermak OS, Borovyk KM, Tytova GYu, Kozhyn MI. The dynamics of 
neurohumoral mediators of vasoconstriction and vasodilation and troponin $\mathrm{i}$ in patients with acute myocardial infarction depending on the degree of concomitant obesity. Wiad Lek. 2020; Sep, 73(9 p. II):1940-3.

12. Schutza DD, Busettob L, Dicker D, Farpour-Lambert N, Pryke R, Toplak H, et al. European practical and patient centred guidelines for adult obesity management in primary care. Obes Facts [Internet]. 2019; Mar, [cited 2021 Mar 07]; 12:40-66. Available from: https://www.karger.com/Article/Fulltext/496183 DOI: $10.1159 / 000496183$

13. Standards of medical care in diabetes - 2019 Abridged for primary care providers American diabetes association. Clin. diabetes J. 2019; Jan, 9 [cited 2021 Mar 07]; 37(1):11-34. Available from: https://clinical.diabetesjournals.org/content/37/1/11 DOI:10.2337/cd180105

14. Wu D, Lei H, Wang Jin-Yu, Zhang Cheng-Lin, Feng $\mathrm{H}$, Fu Feng-Ying, et al. CTRP3 attenuates post-infarct cardiac fibrosis by targeting Smad3 activation and inhibiting myofibroblast differentiation. J. Mol. Med. 2015; Dec, [cited 2021 Mar 08]; 93(12):1311-25. Available from: https://link.springer.com/ article/ 10. 1007\% 2Fs00109-015-1309-8 DOI: 10.1007/s00109015-1309-8. Epub 2015 Jul 3.

\section{УДК 615.127-005.8-06-004-037-08:614.212 ОЦІНКА ВІРОГІДНОСТІ ПОВТОРНОЇ ГОСПІ- ТАЛІЗАЦЇ̈ У ПАЦІЕНТІВ ІЗ ПОСТІНФАРКТ- НИМ КАРДІОСКЛЕРОЗОМ ТА КОМОРБІД- НОЮ ПАТОЛОГІЕЮ}

\section{М.Ю. Котелюх}

Харківський національний медичний університет, кафедра внутрішньої медицини №2 $i$ клінічної імунології та алергології імені академіка Л.Т. Малої,

м. Харків, Украӥна,

ORCID ID: 0000-0001-6090-4835,

e-mail:koteliukh@gmail.com

Резюме. Метою нашого дослідження було вивчення чинників ризику на виникнення випадку повторної госпіталізації у хворих, котрі перенесли гострий інфаркт міокарда із супутнім цукровим діабетом (ЦД) 2 типу або ожирінням.

Матеріали та методи. Було обстежено 262 пацієнтів з постінфарктним кардіосклерозом у поєднанні з ЦД 2 типу або ожирінням. Вони були розподілені на групи: 1 група склала 96 пацієнтів, які не були госпіталізовані до стаціонару протягом 12 місяців, 2 група порівняння - 166 пацієнтів, які були госпіталізовані до стаціонару. Визначення рівня картонектину та адропіну проводили імуноферментними методами. Статистична обробка отриманих даних проведена за допомогою пакета статистичних програм «IBM SPPS Statistics 27.0» та «GraphPad Prism 9.0.2». Для всіх видів аналізу відмінності вважали статистично значущими при $\mathrm{p}<0.05$.

Результати. У результаті дослідження виявлено зниження вмісту CTRP 3 при прогресуванні хронічної серцевої недостатності $(\mathrm{XCH})$ у пацієнтів із постінфарктним кардіосклерозом за наявності та відсутності супутнього ЦД 2 типу або ожиріння. Розроблено оціночну шкалу вірогідності виникнення повторної госпіталізації у пацієнтів із постінфарктним кардіосклерозом та супутнім Џ 2 типу або ожирінням. Нами було проаналізовано клінічні випадки 3 приводу повторної госпіталізації серед пацієнтів із постінфарктним кардіосклерозом за наявності супутньої патологіï.

Висновки. Отримані результаті свідчать про вплив артеріальної гіпертензії, ХCH, ЦД 2 типу та ожиріння на вміст картонектину та адропіну. У результаті виявлено, що картонектин $є$ чинником, що впливає на виникнення випадку повторної госпіталізації. Запропонований спосіб дозволяє оцінити вірогідність виникнення повторної госпіталізації у пацієнтів із постінфарктним кардіосклерозом із коморбідною патологією.

Ключові слова: картонектин, діабет, чинник, госпіталізація, ожиріння.

\section{УДК 615.127-005.8-06-004-037-08:614.212 ОЦЕНКА ВЕРОЯТНОСТИ ПОВТОРНОЙ ГОСПИТАЛИЗАЦИИ У ПАЦИЕНТОВ С ПОСТИНФАРКТНЫМ КАРДИОСКЛЕРОЗОМ И КОМОРБИДНОЙ ПАТОЛОГИЕЙ}

\author{
М.Ю. Котелюх
}

Харьковский нацииональный медицинский университет, кафедра внутренней медиичнны №2 и клинической иммунологии и аллергологии имени академика Л.Т. Малой,

2. Харьков, Украина,

ORCID ID: 0000-0001-6090-4835,

e-mail: koteliukh@gmail.com

Резюме. Целью нашего исследования было изучение факторов риска на возникновение случая повторной госпитализации у больных, перенесших острый инфаркт миокарда с сопутствующим сахарным диабетом (СД) или ожирением.

Материалы и методы. Было обследовано 262 пациентов с постинфарктным кардиосклерозом в сочетании с СД 2 типа или ожирением. Они были разделены на группы: 1 группа составила 96 пациентов, которые не были госпитализированы в стационар в течение 12 месяцев, 2 группа сравнения 166 пациентов, которые были госпитализированы в стационар. Определение уровня картонектина и адропина проводили иммуноферментными методами. Статистическая обработка полученных данных проведена с помощью пакета статистических программ «IBM SPPS 27,0» и «GraphPad Prism версия 9,0». Для всех видов анализа различия считали статистически значимыми при $\mathrm{p}<0,05$.

Результаты. В результате исследования выявлено снижение содержания CTRP 3 при прогрессировании хронической сердечной недостаточности (XCH) у пациентов с постинфарктным кардиосклерозом при наличии и 
отсутствии сопутствующего СД 2 типа или ожирение. Разработано оценочную шкалу вероятности возникновения повторной госпитализации. Нами были проанализированы клинические случаи по поводу повторной госпитализации среди пациентов с постинфарктным кардиосклерозом при наличии сопутствующей патологии.

Выводы. Полученные результаты свидетельствуют о влиянии артериальной гипертензии, $\mathrm{XCH}$, СД 2 типа и ожирения на содержание картонектина и адропина. В результате выявлено, что картонектин является фактором, влияющим на возникновение случае повторной госпитализации. Предложенный способ позволяет оценить вероятность возникновения повторной госпитализации у пациентов с постинфарктным кардиосклерозом с коморбидной патологией.

Ключевые слова: картонектин, диабет, фактор, госпитализация, ожирение.

Стаття надійшла в редакцію 10.03.2021 p. 